\title{
Using Essential Oils to Decrease Potato Tubers Sprouting, Rotting and Insect Infestations during Storage at Ambient Temperature Abd El-Kader, A. E. S. ${ }^{1}$; El-S. L. El-S. Fathy ${ }^{1}$; M. N. A. Gahwash' ${ }^{1}$ and Eftkhar E. Abohatab ${ }^{2}$ ${ }^{1}$ Veg. Dep.; Hort. Res. Institute; ARC; Giza, Egypt. \\ ${ }^{2}$ Plant Protection Research Institute. ARC; Giza; Egypt.
}

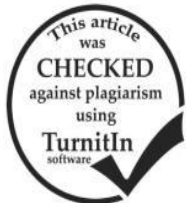

\section{ABSTRACT}

Two storage experiments were carried out at El-Mansoura Horticultural Research Station, Dakahalia Governorate, Egypt, during four months of storage in summer seasons of 2013 and 2014 for studying the effect of seven treatments, i.e,. natural essential oils and selecron on storability and quality of potato tubers and reduction percentages in the infestations potato tubers moth (PTM) under Nawwala condition. These treatments such as ; clove oil, garlic oil, lemonion oil, eucalyptus oil, peppermint oil, basil oil, mixture of these oils and selecron. The obtained results revealed that all storage treatments expect, selecron and control gave different significantly in all studied characters. Using peppermint and clove oils recorded the lowest significant values of sprouting percentage, sprout weight, sprout length and weight of loss percentage in both seasons. The highest values of dry matter \%, starch\% and vitamin C were recorded with peppermint oil, but the lowest sugar percentage was obtained by using the same treatment during two seasons. Results indicated that the effects of essential oils and selecron under storage in Nawwala conditions on Phthorimaea operculla (Zell.) (PTM), after four months of storage, the tubers infestation in control were (4848.67\%), while the mean reduction percentages of infestation ranged between (94.10-98.86\% and 93.23-96.84) during two seasons of 2013/2014 respectively. Peppermint oil, eucalyptus oil, clove oil and mixture oils gave highest mean reduction percentages of infestation such as selecron. Generally, the obtained data indicated that all used oils offered the highest protection. Also, the results in laboratory showed that the effects of oil treatments on larvae PTM recorded significantly variation according to the type of oil and time of exposure which showed fatal action on the larvae of PTM. The efficacy of Peppermint oil, Eucalyptus oil, clover oil and Mixer oils were the best. The percent of mortality ranged between $(76.14$ and $100 \%)$ compared with selecron. Also, all oils were used effected inhibitor action on adults. The inhibition of egg laying and reduction percentages ranged between were $(47.54 \%$ and $95.02 \%)$ of peppermint oil and galaric oils, respectively. This study recommends that it can be sprayed peppermint oil concentration at $(2 \mathrm{~cm} 3 / \mathrm{L} /$ ton) three times during the storage of potato tubers in Nawwala for (4 months) in order to reduce the proportion of sprouting and weight loss and rotting and get a higher percentage of dry matter, starch and less injuries Pferashh (PTM) in tubers. Finally, it could be recommended with peppermint oil, eucalyptus oil, clove oil and mixer oils were the best during storage to obtain the best characters storage and quality. These natural treatments are very safe and potent in improving storability and greatly decreasing PTM insect infection during storage conditions in Nawwala on potato tubers.

\section{INTRODUCTION}

Potato (Solanum tuberosum L.) is an important vegetable crop in Egypt and all over the world. In world tonnage the potato ranks after wheat, rice and maize as the fourth most important crop for human consumption. Potato is seriously infested by the potato tuber moth (PTM), Phthorimaea operculella (Zell.) (Lepidoptera: Gelechiidae) especially, in the field and in stores (Abohatab, 2005). Infested tubers become completely unmarketable. Chemical control of potato tuber moth is a costly input that contaminated the environment, increase resistance to insecticides and can also cause health hazards for the humans. El-Awady (2002) studied the effect of some extracted-essential oils, caraway, dill and thyme and applied at different times. The author found that dipping potato tuber (cv. Spunta) for 20 second in thyme oil $(2 \mathrm{~m} / \mathrm{L})$ at three applications times (30, 60 and 90 days from the beginning of storage) as the best natural, safety and cost effective treatment for storing potato tubers from summer yield, five months at room temperature and its kept potato tuber from PTM.

In potato tuber moth (PTM) larvae attack the tuber forming tunnels, the tunneling results into partial or complete rottening rending it unfit for planting or for human consumption. Finally, the activity of the larvae resulted in a great destruction in the potato vegetations and tubers which in turn adversely affected qualitatively and quantitatively the net crop yield.

The major problems that occur during potato storage are sprouting and rotting due to disease, essential oils of lavender, mint, spearmint, Turkish oregano, Greek oregano, rosemary and sage were assessed. Except for oregano-oils, all other essential oils suppressed potato sprout growth (Vokou et al., 1993). Kleinkopf et al., (2003) and Cheema (2010) on potato showed that spearmint and peppermint oils have been used successfully to prevent sprouting in potatoes for extended storage periods because this oils contain components (evg., S- carvone, eugenol) and hydrogen peroxide- base materials, physically damage the developing sprout and suppers sprout.

Several investigations reported that the application of clove oil was evaluated on shorter dormancy varieties on potatoes and sugar concentrations, in addition cloves oil was less effective in suppressing sprouting, likely due to its slower vaporization compared to dill and spearmint oils (Frazier et al., 2006; Song 2009). The mint oil is effective in maintaining a sprout-free condition in stored potatoes as long as the material is available in sufficient quantity in the head space of potato store. In addition, mint oil gave the highest significant dry matter and the lowest significant total and reducing sugars (Albashir et al., 2011; Ezzat et al., 2011).

Abd El-Moneim et al. (2012) showed that, essential oils (caraway, clove, carvone and eugenol) and gamma irradiation recorded the most suitable methods for inhibiting sprouting of potato tubers. Olsen et al., (2012) indicated that applications of clove oil should be made when sprouts are peeping and preferably no longer than $1 / 2$ inch in length. Depending up on cultivar, not all eyes on a 
potato sprout at the same time so carefully watch the sprouting. Sharma (2012) found that the most effective treatment against sprouting were carvone (68.5\%) limonene $(14.0 \%)$ and piperitenone oxide $(79.2 \%)$ of sprouted tuber at the end of the storage.

Elbashir et al., (2014) indicated that, application of spearmint oil in the field exhibited early break of dormancy, fast sprout growth, high fresh weight loss and high sugar accumulation the combination treatments of sprouting spearmint oil in the field couple with evaporation in cold store controlled the sprout still the third month of storage. The spearmint oil had no adverse effects on reducing sugars, dry matter and ships yield of potatoes.

Using of essential oils as natural alternative prove significant effects in reducing potato storage problems with safe and cost effective aspects added to their antioxidantal impacts against high temperature induce oxidative stress during storage out refrigerators (Frazier et al., 2004; Sonli et al., 2010). On the other hand, essential oils, were used in potent way to control storage insect infection especially Phythorimaea opercuella (Zeller) PTM, (Roman 1984; Lal., 1987).

Oils extracted from E. caryophylatta and T. vulgaris exhibited ovipositional deterring properties against PTM females. However, no eggs were laid by all released PTM females on treated potato tubers during all life span. Reproduction of PTM was significantly reduced when either males or females were exposed to the orange peel vapor (Sharaby, 1988). Also, Alrubeai et al. (2001) added that clove flower buds extract caused inhibition of egg laying by females. Moreover, females exposed to potato tubers treated with $M$. piperta laid few enviable eggs. According to Sharma et al. (1997), M. arvensis had an ovicidal properties against PTM eggs.

Several researchers reported that many essential oils of potato stored at relatively higher temperatures essential oils were most effective as sprout suppressant and reduced infestation of PTM. Cloves flower powder was effective against PTM larvae (Sing et al., 1997; ElGhanam 2005; Abohatab, 2005)

The present work aimed to study the effect of sex natural essential oils and selecron on sprouting storage of potato tubers and estimated the values of dry matter, starch and vitamin $\mathrm{C}$ under Nawwala condition. Also, study to investigate the reduction of population potato tuber moth P. operculella in Nawwala and laboratory.

Materials and Methods

1. The role of some natural products as oils in protecting sprouting and PTM infestation:

Two storage experiments were carried out at Mansoura Horticultural Research Station, Dakahalia Governorate, Egypt, during two successive summer seasons (2013 and 2014). The potato variety tested was spunta of a uniform size tuber $(45-55 \mathrm{~mm})$. It was curried after harvest and divided into groups according to the different treatments.

Table 1. The common and scientific names of oils used in storage of potato under nawwala and laboratory conditions.

\begin{tabular}{|c|c|c|c|c|}
\hline Common name & Scientific name & Family & Formulation & Active ingredients \\
\hline Bud flower clover & Eugenia caryophyllus & Myrtaceae & Oil & Eugenol \\
\hline galaric & Allium sativum & Allecene & $/ /$ & \\
\hline Lemonene & Citrus sp. & Rutaceae & // & Limonene \\
\hline Camphor & Eucalyptus globulus & Mytaceae & $/ /$ & Eucalyptol \\
\hline Spearmint & Mentha pipperta & // & // & Carvone $60 \%$ \\
\hline $\begin{array}{l}\text { Basil } \\
\text { mixture of oils }\end{array}$ & Ocimum basilicum & Lamiaceae & // & Bascllicum \\
\hline selecron & Colropyrophis & organophosr & $72 \% \mathrm{EC}$ & \\
\hline
\end{tabular}

Emulsion of different essential oil treatments were prepared at $2 \mathrm{ml} / \mathrm{L}(\mathrm{v} / \mathrm{v})$ water with $0.05 \%(\mathrm{v} /$ v) Tween 80 as an emulsifier. Control tubers were treated by water with Tween 80 solution $(0.05 \%)$ only. Tubers were sprayed by emulsion and excess liquid was drained. Potato tuber were stored in pile under thick layer of rice straw of $50 \mathrm{~cm}$ height on 25 May -25 September in three vertical row (replications).

During the whole period of storage tubers received three sprays, the first was at the onset, the second was after 1.5 month and the third was also after 1.5 month from the second one.

Spraying oils for four months by using sprayed three times with emulsion of different treatments during the whole period of storage, Intervals between each spray were 40 days on set of storage. Weight of potato 5 $\mathrm{kg}$ all treatments for three replicate.

\section{Studied characteristics:}

The experiment includes three replicates, each group unit contained five $\mathrm{kg}$ potato tubers. At the end of storage period (4 months), potato tubers were checked and the following measurements were recorded:

\section{Sprouting \%.}

Five randomly chosen potato used, the number of eyes, which contained sprouts, were recorded relative to number of total eyes, then calculated per tuber:

$$
\text { Sprouting } \%=\frac{\text { No. of sprouted eyes }}{\text { No. of total eyes }} \times 100
$$

2. Sprout length

3. Sprout weight

4. Weight loss (\%)

5. Number of infested tuber (PTM): tubers were examined by using magnifier10. The number of holes $P$. operculella larvae present in each tuber of replicate was recorded.

Group of tuber was marked and weighted at the beginning and at the end of storage, the damaged tubers were excluded, the average weight ( $\mathrm{g} /$ tuber).

Average weight of marked tubers

(at the beginning or end of storage)

$$
\begin{aligned}
& \text { Average weight }=\frac{}{\text { No. of the same tubers }} \\
& \text { Average weight of tuber at the beginning of storage - } \\
& \text { Average weight of tuber at the end of storage } \\
& \text { 6. Weight loss } \%= \\
& \text { Average weight of tuber at the beginning of storage }
\end{aligned}
$$


7- Dry matter \%

8- Reducing sugars were determined using methods of James (1995).

9- Starch \% was determined according to the methods reported by Nelson (1974).

10- Vitamin $C$ was determined according to the methods described by Mondy and Ponnampalam (1986).

These measurements were recorded at the end of storage period (four months).

Statistical analysis

Obtained data were subjected to statistical analysis using technique of the randomized complete block design according to Sendecor and Cochran (1982) using Costat computer. The treatment means were compared using Dancan's Multiple Rang Test (Duncan, 1955).

\section{2-Laboratory experiments}

For each treatment,9 tubers were divided into three replicates. The treated tubers were transferred to glasses jars $(20 \mathrm{~cm}$ high and $10 \mathrm{~cm}$ diameter). To estimate the toxic effect of tested oils on PTM larvae, newly hatched larvae were put on each replicate (10 larvae / glass). Each glass jar was covered with fine muslin fixed to they rubber bands. Observation was carried out after 24, 48 and 72 hours of treatment for the number of dead larvae.

In addition to two pairs (males and females) of adult moths were introduced into another set of treated tubers to evaluate the Oviposition behavior of PTM females in response to oil extractions (2 pairs / glass jar). Also the number of eggs laid by PTM females were recorded after 48, 72 and 96 hours.
Statistical analysis: The reducing percentage in infestation was corrected by using (Abbott's formula (Abbott, 1925). Also lays eggs was corrected using Abbott's formula (1925) with data under the laboratory. " Costat" a product of cohort soft ware was used to differentiation between means and L.S.D. The reduction percentages of the the mortality were calculated using the following equation:

$$
\text { Mortality } \%=\frac{\text { No. of life larvae in control }- \text { No. of life larvae in treatment }}{\text { No. of life larvae in control }} \times 100
$$

\section{RESULTS AND DISCUSSION}

Sprouting, sprout weight, sprout length and weight loss:

All essential oils treatments greatly suppressed the incidence of sprouting, sprouts weight, sprouts length and weight loss compared with control and selecron (Table 2 and Figs. 1\&2). The data showed that the application of peppermint and clove oils have significantly reduced sprouting percentage, sprout weight, sprout length and weight loss percentage in both seasons but the good treatments with peppermint oil to reduce sprouting percentage, sprout weight, sprout length the most superior ones clove oil and lemonine were peppermint oil followed by and weight of loss percentage in both season. Similar results were obtained by Vokou et al (1993); Kleinkopf et al (2003); Frazier et al (2006); Song (2009); Cheema (2010), Elbashir et al (2011); Olsene et al (2012); Sharma (2012); Castilla et al (2013) and Elbashir et al (2014).

Table 2. Effect of essential oils and selecron on sprouting\%, sprout weight, sprout length and weight of loss

\begin{tabular}{|c|c|c|c|c|c|c|c|c|}
\hline \multirow{2}{*}{ Treatments } & \multicolumn{2}{|c|}{ Sprouting \% } & \multicolumn{2}{|c|}{ Sprouts weight (gm) } & \multicolumn{2}{|c|}{ Sprouts length $(\mathrm{cm})$} & \multicolumn{2}{|c|}{ Weight of loss \% } \\
\hline & S1 & S2 & S1 & S2 & S1 & S2 & S1 & S2 \\
\hline Control & $56.47 \mathrm{a}$ & $55.55 a$ & $4.67 a$ & $4.95 a$ & $4.42 \mathrm{a}$ & $5.70 \mathrm{a}$ & $27.64 a$ & $33.25 \mathrm{a}$ \\
\hline Clove oil & $10.46 \mathrm{~d}$ & $14.50 \mathrm{~d}$ & $1.73 d$ & $1.49 \mathrm{f}$ & $1.00 \mathrm{de}$ & $1.18 \mathrm{f}$ & $10.55 \mathrm{~cd}$ & $11.06 \mathrm{c}$ \\
\hline Garlic oil & $13.68 \mathrm{~cd}$ & $17.91 \mathrm{~cd}$ & $2.33 \mathrm{c}$ & $2.38 \mathrm{de}$ & $2.05 \mathrm{c}$ & $2.17 \mathrm{c}$ & $13.22 \mathrm{c}$ & $12.23 \mathrm{c}$ \\
\hline Lemonine oil & $10.87 \mathrm{~d}$ & $16.11 \mathrm{~cd}$ & $1.90 \mathrm{~d}$ & $2.27 \mathrm{e}$ & $1.40 \mathrm{cde}$ & $1.50 \mathrm{e}$ & $12.30 \mathrm{c}$ & $12.35 \mathrm{c}$ \\
\hline Euculyptus oil & $11.10 \mathrm{~d}$ & $16.35 \mathrm{~cd}$ & $1.90 \mathrm{~d}$ & $2.63 \mathrm{c}$ & $1.70 \mathrm{~cd}$ & $1.80 \mathrm{de}$ & $12.42 \mathrm{c}$ & $12.22 \mathrm{c}$ \\
\hline Peppermint oil & $5.48 \mathrm{e}$ & $9.10 \mathrm{e}$ & $1.00 \mathrm{e}$ & $1.15 \mathrm{~g}$ & $0.79 \mathrm{e}$ & $0.84 \mathrm{~g}$ & $8.69 \mathrm{~d}$ & $10.73 c$ \\
\hline Basal oil & $13.78 \mathrm{~cd}$ & $19.32 \mathrm{c}$ & $2.33 \mathrm{c}$ & $2.66 \mathrm{c}$ & $2.05 \mathrm{c}$ & $2.21 \mathrm{c}$ & $13.25 \mathrm{c}$ & $11.40 \mathrm{c}$ \\
\hline Mixture oils & $15.66 \mathrm{c}$ & $19.93 c$ & $2.40 \mathrm{c}$ & $2.51 \mathrm{~cd}$ & $1.99 \mathrm{c}$ & $2.10 \mathrm{~cd}$ & $13.34 \mathrm{c}$ & $13.56 \mathrm{c}$ \\
\hline Selecron & $30.31 b$ & $31.38 \mathrm{~b}$ & $3.63 b$ & $3.64 b$ & $3.07 \mathrm{~b}$ & $3.17 \mathrm{~b}$ & $18.43 \mathrm{~b}$ & $19.40 \mathrm{~b}$ \\
\hline
\end{tabular}
$\%$ after four months storage during 2013 and 2014 seasons.

Means sharing similar letter (s) don't differ significantly at $\mathrm{p}=\mathbf{0 . 0 5}$ level according to Duncan's multiple range test.
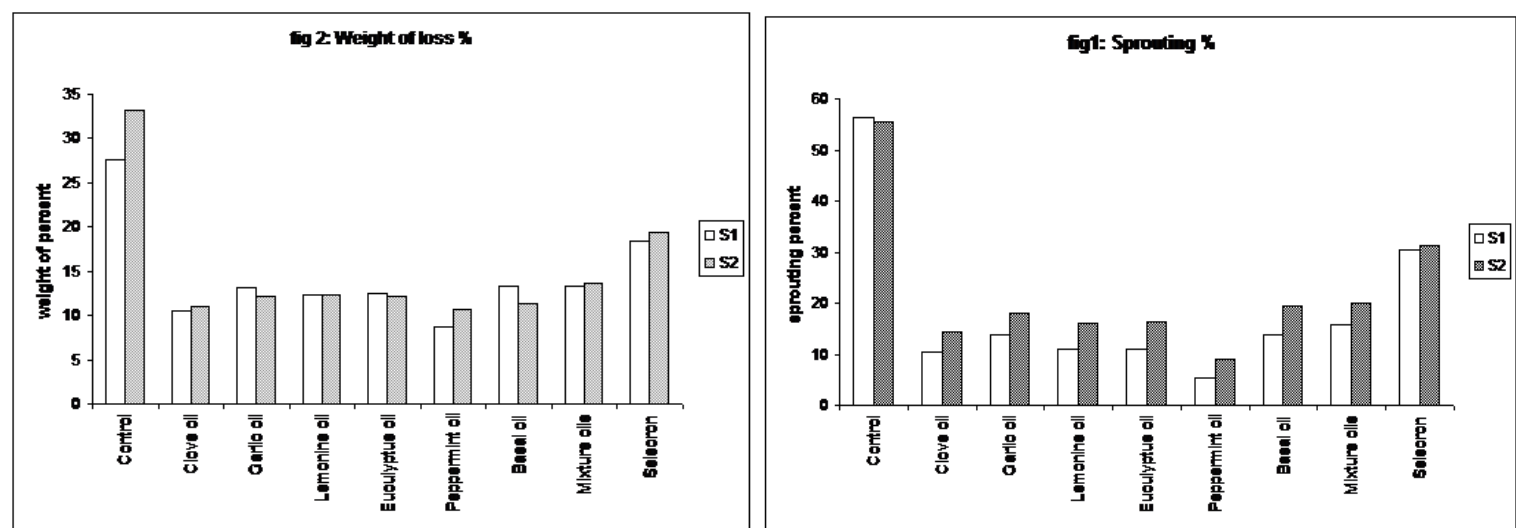

Fig. 1,2. Effect of essential oils and selecron on sprouting and weight loss after four months storage during 2013 and 2014 seasons.

As regards, the inducible oxidative stress known to cause excessive $\mathrm{O}_{2}$ diffusion, respiration rise, carbohydrate degradation and sugar depletion. In turn, providing more energy and structural components for the rapidly developing sprout tissues, since the sprouts servas as a powerful sinks for the materials (van and Hartmans, 1987) 
Once again, the best storability case of tuber treated with antioxidant rich essential oils, includes the lowest sprouting, sprout weight, sprout length and weight loss percentage added to their preserved constituents( Table 1).

There by suppressed the oxidative stress destructive effects and in turn allowing less available energy and mobilized reserves, reducing sprouting and weight losing incidence.

Mean while these essential oils suppressed sprouting via their monoterpenes basic constituents which known to inhibit mitochondrial respiration (Lorber and Muller, 1980), reduce carbohydrate degradation and sugars changes (Table 3)

Table 3. Effect of essential oils and selecron on DM\%, starch, reducing sugar and vitamin C after four months storage during 2013 and 2014 seasons.

\begin{tabular}{|c|c|c|c|c|c|c|c|c|}
\hline \multirow{2}{*}{ Treatments } & \multicolumn{2}{|c|}{ DM \% } & \multicolumn{2}{|c|}{ Starch \% } & \multicolumn{2}{|c|}{ Reducing sugar } & \multicolumn{2}{|c|}{ Vitamin C } \\
\hline & S1 & S2 & S1 & S2 & S1 & S2 & S1 & S2 \\
\hline Control & $17.92 \mathrm{~d}$ & $17.90 \mathrm{~d}$ & $16.71 \mathrm{e}$ & $16.41 \mathrm{~h}$ & $1.22 \mathrm{a}$ & $1.23 \mathrm{a}$ & $12.87 \mathrm{i}$ & $12.33 \mathrm{~h}$ \\
\hline Clove oil & $20.06 b$ & $20.21 \mathrm{ab}$ & $18.67 \mathrm{ab}$ & $18.70 \mathrm{~b}$ & $0.72 \mathrm{fg}$ & $0.71 \mathrm{~g}$ & $15.46 b$ & $16.20 \mathrm{~b}$ \\
\hline Garlic oil & $19.60 \mathrm{bc}$ & 19.49 bc & $18.24 \mathrm{bc}$ & $18.36 \mathrm{~d}$ & $0.87 \mathrm{~cd}$ & $0.90 \mathrm{de}$ & $14.47 \mathrm{~d}$ & $14.17 \mathrm{e}$ \\
\hline Lemonine oil & $19.91 b$ & $20.00 \mathrm{~b}$ & $18.47 \mathrm{ab}$ & $18.55 \mathrm{c}$ & $0.78 \mathrm{ef}$ & $0.76 \mathrm{f}$ & $14.67 \mathrm{c}$ & $14.83 \mathrm{~d}$ \\
\hline Euculyptus oil & $19.73 b$ & $19.89 b$ & $18.32 \mathrm{abc}$ & $18.39 d$ & $0.83 \mathrm{de}$ & $0.86 \mathrm{e}$ & $13.13 \mathrm{~h}$ & $15.87 \mathrm{c}$ \\
\hline Peppermint oil & $20.62 \mathrm{a}$ & $21.26 \mathrm{a}$ & $18.81 \mathrm{a}$ & $18.83 a$ & $0.63 \mathrm{~g}$ & $0.70 \mathrm{~g}$ & $16.23 \mathrm{a}$ & $18.53 \mathrm{a}$ \\
\hline Basal oil & $19.93 b$ & $20.18 c$ & $18.17 \mathrm{bc}$ & $18.22 \mathrm{e}$ & $0.92 \mathrm{e}$ & $0.93 \mathrm{~d}$ & $14.22 \mathrm{e}$ & $14.17 \mathrm{e}$ \\
\hline Mixture oils & $19.18 \mathrm{c}$ & $19.40 \mathrm{bc}$ & $17.95 \mathrm{c}$ & $17.93 f$ & $0.99 \mathrm{~b}$ & $0.97 \mathrm{c}$ & $14.07 f$ & $14.10 \mathrm{f}$ \\
\hline Selecron & $18.42 \mathrm{~d}$ & $18.39 \mathrm{~cd}$ & $17.49 \mathrm{~d}$ & $17.41 \mathrm{~g}$ & $1.18 \mathrm{a}$ & $1.15 \mathrm{~b}$ & $13.40 \mathrm{~h}$ & $12.77 \mathrm{~g}$ \\
\hline
\end{tabular}

Means sharing similar letter (s) don't differ significantly at $\mathrm{p}=0.05$ level according to Duncan's multiple range test.

All storage treatments gave highest significant values in dry matter percentage, starch percentage and vitamin $\mathrm{C}$ but, this treatments recorded lowest reducing
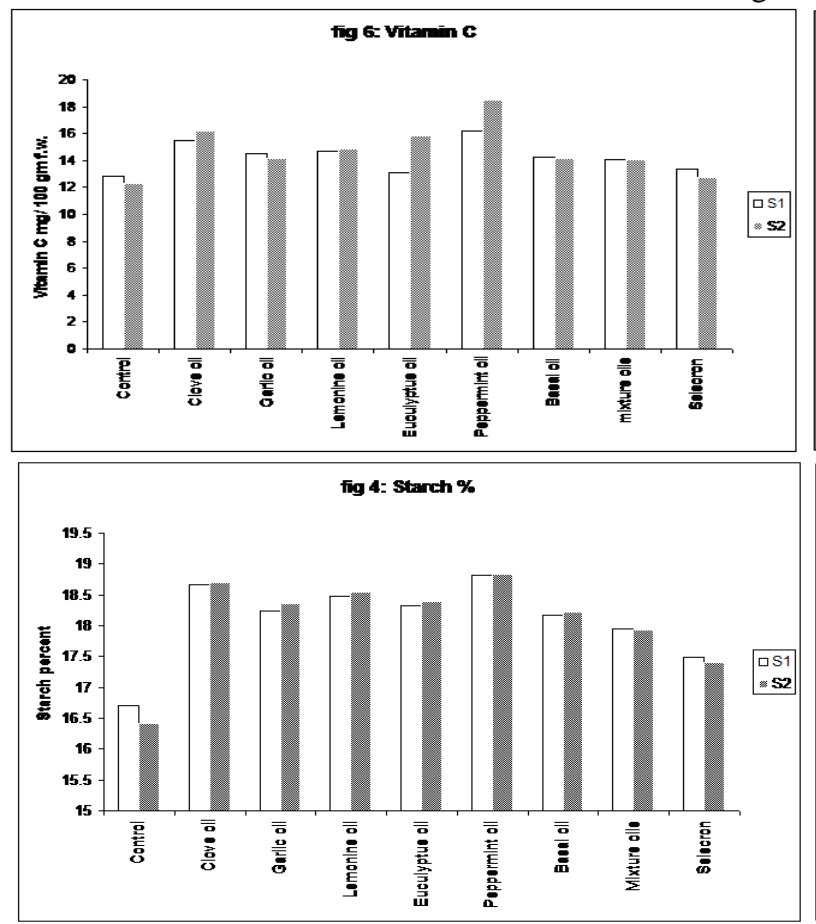

sugar compared with the control in both seasons (Table 3 and Figs $3 \& 4 \& 5 \& 6)$.

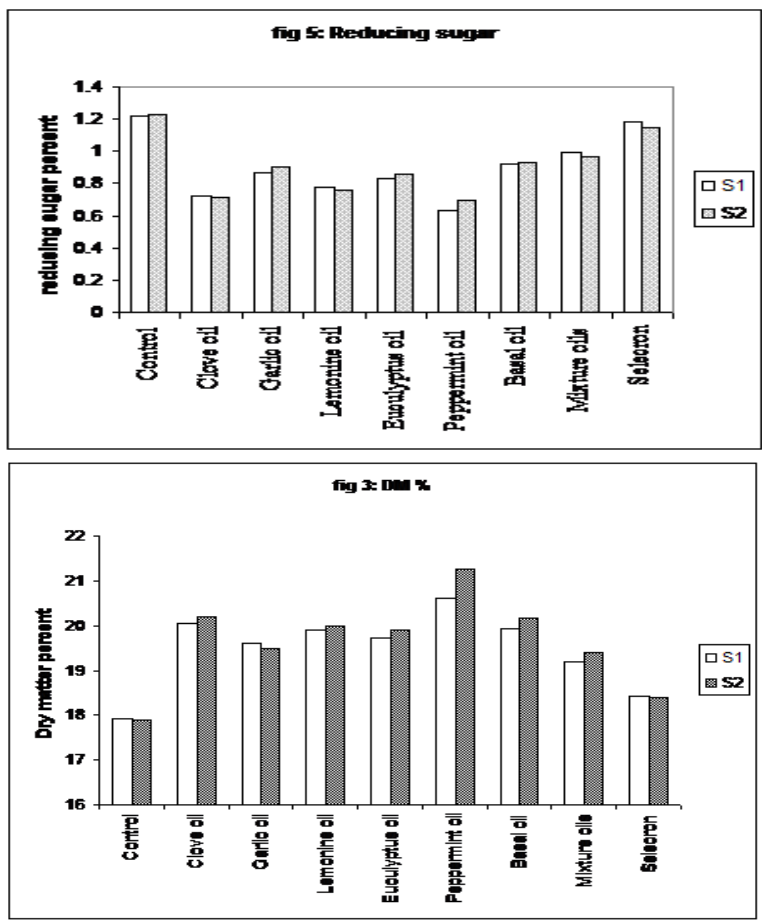

Figs. 3,4,5,6. Effect of essential oils and selecron on DM\%, starch \% reducing sugar and Vitamin C after four months storage during 2013 and 2014 seasons.

Similar results were obtained by Vokou et al (1993), Kleinkopf et al (2003), Farzier et al (2006); Sheema (2010); Elbashir et al (2011); Ezzat (2011); Castilla et al (2013) and Elbashir et al (2014). The reducing sugars content increased in treatments that had a high percentage of infected and sprouted tubers Mahmoud, (1973).

Elbashir et al (2011) found that the oil extracted from mint plants is effective in maintaining a sprout free condition in stored potatoes as long as the material is available in sufficient quantity in the head space of potato store.
Generally the used of essential oils led to slowing down the activity of carbohydrates and protein breakdown associated enzymatic systems as well as respiration and energy metabolism enzymes (Trevanion and Kruger 1991, El-Awady et al (2006).

\section{B-Examines insects}

I- Effect of natural oils and pesticides under storage nawwala conditions on Phthorimae operculle (P.T.M)

The data in (Table 4) indicated that, after four months of storage, $48-48.67 \%$ of tubers were infested in the control and the mean reduction percentages in the infestations ranged between (94.10- 98.86\% and93.2396.84) during two seasons. Peppermint oil, Clove oil , 
Mixture oils, and Eucalyptus oil give the highest mean reduction percentages for oils compared with selecron. Singh et al. (1997). Tested the activity of 13 essential oils on potatoes stored at relatively higher temperatures. Essential oils of Mentha piperata and spictata were most effective as sprout suppressant and reduced the infestation of PTM.
Generally the obtained data indicated that all used oils offered the highest protection to the stored tubers. None of the treatments had an adverse effect on germination or on the yield of a subsequent crop.

Table 4. Mean Percentage of reduction in PTM infestation on potato tubers treaded with cloves, galaric, lamonin, Eucalyptus oil, Peppermint ,Basil, mixture of oils, and selecron during four months of storage under nawwala conditions during seasons 2013/2014).

\begin{tabular}{|c|c|c|c|c|c|c|c|c|}
\hline \multirow[t]{2}{*}{ Treatments } & \multicolumn{2}{|c|}{$\begin{array}{c}\text { \% Reduction of infestation } \\
1^{\text {st }} \text { (inspection) }\end{array}$} & \multicolumn{2}{|c|}{$\begin{array}{c}\text { \% Reduction of infestation } \\
2^{\text {nd }} \text { (inspection) }\end{array}$} & \multicolumn{2}{|c|}{$\begin{array}{c}\% \text { Reduction of infestation } \\
\mathbf{3}^{\text {rd }} \text { (inspection) }\end{array}$} & \multicolumn{2}{|c|}{$\begin{array}{c}\text { Mean reduction } \% \\
\text { percentages }\end{array}$} \\
\hline & S1 & S2 & S1 & S2 & S1 & S2 & S1 & S2 \\
\hline Control & 14 & 16 & 44 & 52 & 88 & 76 & 48.67 & 48.00 \\
\hline Clove oil & 92.86 & 93.75 & 97.73 & 96.15 & 98.86 & 98.68 & 96.48 & 96.19 \\
\hline Garlic oil & 85.71 & 93.75 & 97.73 & 96.15 & 98.86 & 97.37 & 94.10 & 95.76 \\
\hline Lemonine oil & 85.71 & 87.5 & 97.73 & 96.15 & 98.86 & 96.05 & 94.10 & 93.23 \\
\hline Euculyptus oil & 92.86 & 93.75 & 97.73 & 98.08 & 98.86 & 97.37 & 96.48 & 96.40 \\
\hline Peppermint oil & 92.86 & 93.75 & 97.73 & 98.08 & 100 & 98.68 & 96.86 & 96.84 \\
\hline Basial oil & 85.71 & 87.5 & 97.73 & 96.15 & 98.86 & 96.05 & 94.10 & 93.23 \\
\hline Mixture oils & 100 & 93.75 & 97.73 & 98.08 & 98.86 & 98.68 & 98.86 & 96.84 \\
\hline Selecron & 92.86 & 93.75 & 97.73 & 100 & 100 & 98.68 & 96.86 & 99.56 \\
\hline
\end{tabular}

I -Effect of plant oils on potato tuber infestation by

PTM under laboratory conditions :-

1- Effected of essential oils on the $1^{\text {st }}$ instar of PTM larvae:-

Results in Table (5) indicated the effect on larvae which varied significantly according to the type of oil and time of exposure comparatively. The oil treatments that are used, show fatal action on the larvae of PTM. The efficacy of Peppermint oil , Eucalyptus oil, Mixer

oils, and clover oil were the best. The percent of mortality ranged between 76.14 and $100 \%$ for oils compared with selecron. The percent of mortality after 24 hours was 89.28 and the mortality percent increased to reach $100 \%$ after 48 hours, while the percent of mortality with Galaric, Basil. and Lamonin were 7.14, 53.57and 57.14 after 24 hours respectively. The highest mortality percent of larvae was recorded on the first day for most treatment after treated the potato tuber.

Table 5. Effect of essential oils cloves, galaric, lamonin, Eucalyptus , Peppermint „Basil, - mixture of oils, and selecron on mortality of the PTM 1st instars larvae under laboratory conditions.

\begin{tabular}{|c|c|c|c|c|c|c|}
\hline \multirow{2}{*}{ Treatments } & \multicolumn{2}{|c|}{ 24(hours) } & \multicolumn{2}{|c|}{ 48(hours) } & \multicolumn{2}{|c|}{ 72(hours) } \\
\hline & Mean mortality & Reduction & Mean mortality & Reduction & Mean mortality & Reduction \\
\hline Control (A.T.) & $0.67 \pm 0.33 \mathrm{~d}$ & 6.66 & $1.33 \pm 0.33 c$ & 20 & $1.00 \pm 0.58 \mathrm{c}$ & 23.31 \\
\hline Clove oil & $4.66 \pm 0.33 a$ & 42.85 & $4.33 \pm 0.33 c$ & 87.5 & $0.67 \pm 0.33 \mathrm{ab}$ & 95.24 \\
\hline Garlic oil & $1.33 \pm 0.88 \mathrm{a}$ & 7.14 & $6.33 \pm 0.33 b$ & 70 & $1.67 \pm 0.67 \mathrm{ab}$ & 90.47 \\
\hline Lemonine oil & $6.00 \pm 0.58 \mathrm{ab}$ & 57.14 & $1.33 \pm 0.33 c$ & 66.66 & $1.33 \pm 0.33 b c$ & 80.95 \\
\hline Euculyptus oil & $9.00 \pm 0.58 \mathrm{a}$ & 89.28 & $1.00 \pm 0.58 c$ & 100 & $0.00 \pm 0.00 \mathrm{a}$ & 100 \\
\hline Peppermint oil & $9.00 \pm 0.58 a$ & 89.28 & $1.00 \pm 0.58 \mathrm{a}$ & 100 & $0.00 \pm 0.00 \mathrm{a}$ & 100 \\
\hline Basal oil & $5.67 \pm 0.33 b c$ & 53.57 & $1.00 \pm 0.58 c$ & 62.5 & $1.33 \pm 0.33 c$ & 76.1 \\
\hline Mixture oils & $9.00 \pm 0.58 c$ & 89.28 & $1.33 \pm 0.33 c$ & 100 & $0.00 \pm 0.00 \mathrm{c}$ & 100 \\
\hline$\underline{\text { Selecron }}$ & $8.33 \pm 0.33 \mathrm{~d}$ & 89.28 & $1.33 \pm 0.33 c$ & 100 & $0.00 \pm 0.00 \mathrm{c}$ & 100 \\
\hline LSD at $0.05 \%$ & 1.70 & & 1.32 & & 0.98 & \\
\hline $\mathrm{F}$ & 29.05 & & 16.06 & & 4.18 & \\
\hline
\end{tabular}

Generally, the efficacy of Peppermint, Eucalyptus, Mixer oils and Cloves were the best Few numbers of larvae penetrate the tubers but they were not capable to complete their life cycle and died inside the tubers. Similar conclusion was obtained by Singh et al. (1997) and Abohatab (2005) they found that, water extract of clove flower buds (thym and spearmint), exhibited fatal effect on PTM larvae.).

Statistical analysis showed that there were significant differences $\left(\mathrm{F}=29.05^{* *}\right.$ and $\left.\mathrm{LSD}=1.70\right)$ after 24 hours

2- Effect of some essential oils and selecron on lay egg of adults PTM :-

The results obtained in Table (6) indicated the effect of plant oils and insecticide Selecron on reduction and inhibition of egg laying by adult essential of PTM. The effect increased with an increased of oil and exposure time. The treatment of Eucalyptus oil and
Selecron gave the highest effect after 24 hours (81.05) and $72.83 \%$.resp.. The efficacy of oils gave the highest mortality after 96 hours $(95.02 \%)$ for Peppermint oil. The heights reduction to Cloves was (73.67) \% after 48 hours, Mixer oils oil reduction the percent reached $75.58 \%$ after 72 hours. The inhibition of egg laying and reduction percentages ranged between 95.02\% and $47.54 \%$ for Peppermint and Galaric oils respectively. Generally, all used oils gave on effective inhibitor action on adults. Reproduction was significantly reduced when either males or females were exposed to potato with treatments oils.

All tested oil exhibited Oviposition deterring properties against PTM females . Also, Sharaby (1988) found that, egg viability ranged from 0.0 to 30.0 when the moths were exposed to orange peel oil. Sharaby, 1988). The effect increased with the increase of oil 
exposure time. Moreover, females exposed to potato tubers treated with $M$. piperta laid few enviable eggs.
Statistical analysis showed that there were high significant differences $\left(\mathrm{F}=48.25^{* *}\right.$ and $\left.\mathrm{LSD}=3.32\right)$ after 24 hours.

Table 6. Effect of essential oils cloves, galaric, lamonin, Eucalyptus, Peppermint ,Basil, - mixture of oils, and selecron on redaction lays egg percentage of the PTM adults under laboratory conditions.

\begin{tabular}{|c|c|c|c|c|c|c|}
\hline \multirow{2}{*}{ Treatments } & \multicolumn{2}{|c|}{ \%Egg 48 (hours) } & \multicolumn{2}{|c|}{$\%$ Egg 72 (hours) } & \multicolumn{2}{|c|}{ \% Egg96 (hours) } \\
\hline & Mean egg (No.) & Reduction \% & Mean egg (No.) & Reduction (No.) & Mean egg (No.) & Reduction \% \\
\hline Control (A.T.) & $30.66 \pm 1.15 \mathrm{f}$ & & $28.66 \pm 1.52 \mathrm{e}$ & & $20.33 \pm 6.11 \mathrm{e}$ & \\
\hline Clove oil & $11.66 \pm 1.52 \mathrm{a}$ & 67.40 & $13.0 \pm 2.46 \mathrm{a}$ & 73.67 & $10.66 \pm 1.15 \mathrm{a}$ & 67.21 \\
\hline Garlic oil & $10.00 \pm 2.00 \mathrm{~b}$ & 61.96 & $7.66 \pm 1.52 b$ & 54.65 & $6.66 \pm 0.57 b$ & 47.54 \\
\hline Lemonine oil & $15.66 \pm 1.15 \mathrm{bc}$ & 54.35 & $17.66 \pm 1.15 \mathrm{c}$ & 41.86 & $7.33 \pm 0.57 b c$ & 63.93 \\
\hline Euculyptus oil & $6.00 \pm 0.00 \mathrm{~cd}$ & 81.05 & $7.33 \pm 1.15 \mathrm{~d}$ & 74.42 & $3.00 \pm 1.00 \mathrm{c}$ & 85.25 \\
\hline Peppermint oil & $12.33 \pm 2.51 \mathrm{bcd}$ & 66.31 & $11.00 \pm 2.64 \mathrm{c}$ & 61.63 & $8.33 \pm 1.52 b c$ & 95.02 \\
\hline Basal oil & $11.33 \pm 1.15 \mathrm{~cd}$ & 63.04 & $11.66 \pm 0.57 \mathrm{c}$ & 59.31 & $9.00 \pm 1.00 \mathrm{bc}$ & 55.47 \\
\hline Mixture oils & $10.66 \pm 3.05 \mathrm{~cd}$ & 65.22 & $7.00 \pm 1.00 \mathrm{c}$ & 75.58 & $6.00 \pm 1.00 \mathrm{bc}$ & 70.49 \\
\hline Selecron & $8.33 \pm 1.20 \mathrm{de}$ & 72.83 & $11.0 \pm 1.73 \mathrm{~d}$ & 61.63 & $7.67 \pm 0.58 \mathrm{~cd}$ & 62.60 \\
\hline LSD at $0.05 \%$ & 3.32 & & 2.67 & & 3.61 & \\
\hline $\mathrm{F}$ & 48.25 & & 68.73 & & 18.93 & \\
\hline
\end{tabular}

Means sharing similar letter (s) don't differ significantly at $\mathrm{p}=\mathbf{0 . 0 5}$ level according to Duncan's multiple range test.

Generally, it could be indicated that peppermint oil , Eucalyptus oil ,cloves, mixture of oils, galaric, lamonin, , ,Basil, - exhibited a reliable protection from PTM infestation .Also, extracted oils were safety and reduced sprout damage during storage (Raman \& Booth, 1983a ,El-Awady, 2002, and Abohatab(2005).

\section{Economic evaluation:}

Net profit of final products was estimated as a relationship between gross return (L.E 3410/ton) was obtained from application of peppermint oil treatment in comparison with other treatments. Thus, this treatment proved to be highly economical for potato storing. It could be concluded that using peppermint oil or Euculyptus oil as the best safe, natural, good quality and high-benefit treatments.

Table 7 : Effect of essential oils and selecron on net return after 4 months storage.

\begin{tabular}{|c|c|c|c|c|c|c|}
\hline Treatments & $\begin{array}{c}\text { Gross return* } \\
\text { (L.E. ton-1) }\end{array}$ & $\begin{array}{c}\text { Treatment cost } * * \\
\text { (L.E. ton-1) }\end{array}$ & $\begin{array}{l}\text { Total cost } * * * \\
\text { (L.E. ton-1) }\end{array}$ & $\begin{array}{l}\text { Net return } \\
\text { (L.E. ton-1) }\end{array}$ & $\begin{array}{c}\text { Benefit / cost } \\
\text { ratio } * * * *\end{array}$ & Order \\
\hline$\overline{\text { Control (A.T.) }}$ & 1500 & 0.00 & 1500 & 0.00 & 0.00 & 6 \\
\hline Clove oil & 4500 & 67 & 1567 & 2933 & 1.87 & 3 \\
\hline Garlic oil & 4750 & 90 & 1590 & 3160 & 1.99 & 2 \\
\hline Lemonine oil & 4500 & 67 & 1567 & 2933 & 1.87 & 3 \\
\hline Euculyptus oil & 4750 & 90 & 1590 & 3160 & 1.99 & 2 \\
\hline Peppermint oil & 5000 & 90 & 1590 & 3410 & 2.14 & 1 \\
\hline Basal oil & 4500 & 67 & 1567 & 2933 & 1.87 & 3 \\
\hline Mixture oils & 4000 & 67 & 1567 & 2433 & 1.55 & 4 \\
\hline Selecron & 2000 & 50 & 1550 & 450 & 0.29 & 5 \\
\hline
\end{tabular}

* Gross return of final products was estimated according to the quality of potato tuber at the end of storage (healthy tuber, free in virtual and physiological defects and good quality for processing products) and ranging from L.E 1500: 5000/ton.

** Treatment cost was calculated according to the following price: Clove oil L.E 150/L, Garlic oil L.E 200/L, Lemonine oil L.E 150/L, Euculyptus oil L.E 200/L, Peppermint oil L.E 200/L, Basal oil L.E 150/L, Mixture oils L.E 150/L and Selecron L.E 100/L. *** Total costs were price of potato tubers per ton before storage which equal nearly L.E. 1500, plus treatment cost. **** Benefit/cost ratio was divided by net return in total costs.

\section{CONCLUSION}

It be concluded with storing potato at ambient temperature (nawwala conditions) for four summer month by spraying peppermint essential oil three times for strong reduction in sprouting, weight loss and damage. Also, to obtain higher storability (starch and dry matter). At the same time the least infection with storage PTM insect.

\section{REFERENCES}

Abbott, W. S. (1925). A method of computing the effectiveness of insecticide. J. Econ. Entomol., 18: 265-267.

Abdel-Moneim M.R.A; H.S. El-Beltagl; A.A.Aly and A.E. El-Ansary (2012) The impact of Y-Irradiation, Essential oils and Iodine on biochemical components and metabolism of potato tuber during storage. Note Bot. Hortic. Agrobo 40(2): 129-139.

Ali, K.S.T; C. Hetner; L. Iadislav and V. Currie (1997). The Potato association of America. Amer. Potato J.; 74: 415-425.
Cheema, M.U.A. (2010). Dormancy and sprout control in root and tuber crops. Thesis submitted in partial fulfillment for the degree of Doctor of philosophy natural Resoucres Institute Univ. of Creen . Uk.

Duncan, B.D. (1955). Multiple range and multiple F test. Biometrics, 1-42.

Eftkhar E,M, Abohatab (2005) STUDIES ON POTATO TUBER WORM ON SOME SOLANACEOUS CROPS. PhD Thesis, Economic Entomology Department, Fac. Agric., Mansoura Univ.

El-Awady, Aml, A. (2002). Studies on potato storage. M. Sci. Thesis, Fac. Agric. Mansoura Univ., 130 p.

El-Bashir, H.A.; R.A. Abdel-Halim and K.S. Yousif (2011). Effect of spearmint oil on sprouting and processing quality of Diamante and Sinara potato varieties. Current Res. J. of Biological Sciences 3(5): 530-534.

El-Bashir, H.A.; R.A. Abdel-Halim and K.S. Yousif (2014). Efficiency of different applications of spearmint on storability and processing quality of two potato varieties. Journal of Agric-Food and Applied Sciences vol. 2(5), pp 124-133, 31. 
El-Ghanam, M. S. M. (2005). Studies on potato tuber moth, Phthorimaea operculella (Zeller) (Gelechiidae: Lepidoptera) and its control. M. Sc. Thesis, Fac. Agric., Moshtohor, Zagazig Univ., 111 pp.

Ezzat, A.S.; E.N. El-Banna and A.A. El-Awady (2011). Effect of foliar spray with natural sprout inhibitors on productivity and storability of some new potato varieties Egypt J. Hort., 38 (1): 23-49.

Frazier Mary J; G.E. Kleinkopf and N. Oslen (2006). Clove oil for potato sprout and silver scurf suppressionin storage. Presented at the Idaho Potato. Conference on January 19.

James C.S. (1995). Analytical chemistry of food. SealeHayne Faculty of Agriculture, Food and Land use, Dept. Agric. Food stud. Univ. Polymouth, UK. 1: 9697.

Kleinkopf, G.E.; N.A. Oberg and N.L. Oslen (2003). Sprout Inhibition in storage: Current Status, new chemistries and natural compounds. Amer. J. of Potato Res. 80: 317-327.

Lal, L. (1987). Studies on natural repellents against potato tuber moth, phthorimaea operculella. (Zeller) in country stores. Potatas Res; 30: 329-334.

Lorber, p. and W. H.Muller. (1980). Volatile growth inhibitors produced by Salvia leucophlla: Effect on metabplic activity in mitochondrial suspensions. Physiol.Ecol. 5: 68-75

Mahmoud A.A.E (1973), Change in nutritive values of gamma irradiation horticultural fruits during different storage periods. M.Sc. Thesis, Hort., Dep. Fac. Agric., Ain Shams Univ., Cairo, Egypt.

Mondy, N.I. and R. Ponnampalam (1986). Potato quality as affected by source of magnesium fertilizer: Nitrogen, minerals and ascorbic acid. J. Food Sci., 51: 352-358.
Nelson, N. (1974). A photometry adaptation of the somogy methods for determination of glucose. d. Bio. Chem. 195: 19-23.

Olsen, N.; M.J. Frazier and Kleinkopf (2012). Potato sprout suppression from clove oil.http: // www.kimberly . uidaho. Edu/potatoes/CIS 1120.pdf.

Raman, K.V. (1984). Evaluation of synthetic sex pheromone funnel trap for potato tuber worm moth (Lepidoptrea: Gelechidiidae). Entomol, 3(6): 61-64.

Sharma, A. (2012). Essential oil as organic and Alternative methods for potato (Solanum tuberosum L.) sprout control in storage. International J. of Engineering and Mathematical Sciences. vol.(1), Issue-1, pp 34-39.

Singh, G.; I. P. S. Kapoor; S. K. Pandey and G. Singh (1997). Studies on essential oils. Part 7. Natural sprout inhibitors for potatoes. Pesticide Res. J., 9 (1): 121-124.

Snedecor, G.W. and Cochran, W.G. (1982). Statistical methods. Lowa State Univ. Press USA. 6th Ed. pp 34-93.

Song, X. (2009). The impact of dill weed, spearmint and clove essential oils on sprout suppression in potato tubers. Master of science in the department of plant Science. Univ. of Sakatchewan Saskatoon, SK.

Trevanion, S.J. and N.J. Kruger (1991), Effect of temperature on the kinetic properties of pyrophosphate fructose -6phosphate phosphotransferase from potato tuber. J. Plant. Physiol., 137: 753-759.

Van. Es. A; K.J. Hartmans (1987). Sttructura and chemical composition of the potato. In: Rastovski. A., Van. Es. A. (eds): Storage of potatoes. pudoc, Wageningen: $39,47 . S$

Vokou, D.; S. Vareltzidov and P. Katinakis. (1993). Effects of aromatic plants on potato storage: sprout suppression and antimicrobial activity. Agriculture, Ecosystem and Environment, 43: 223-235.

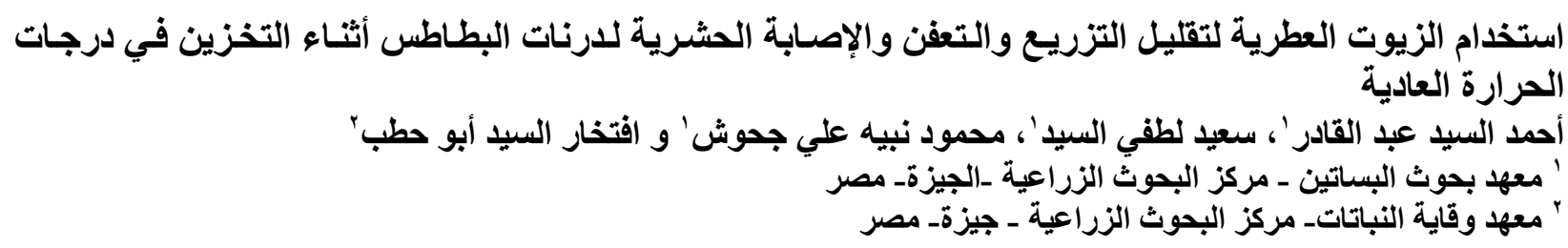

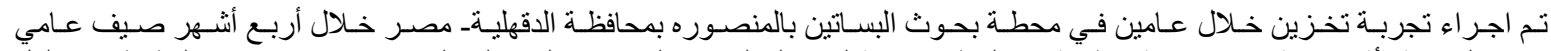

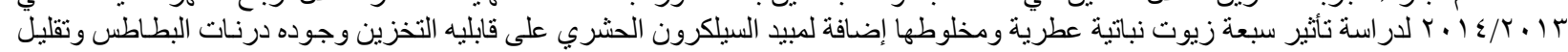

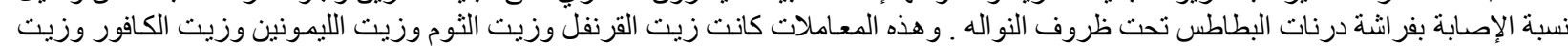

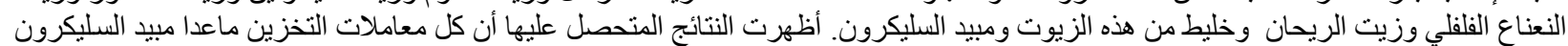

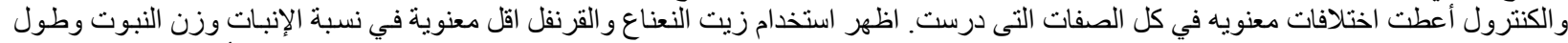

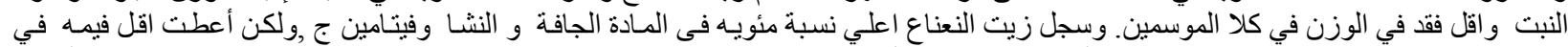

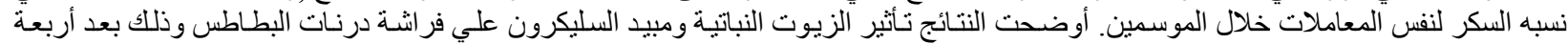

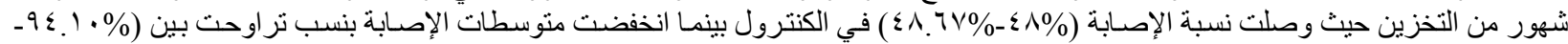

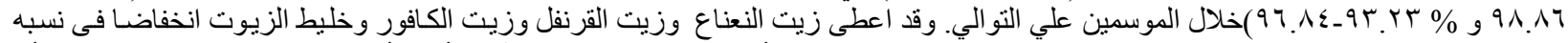

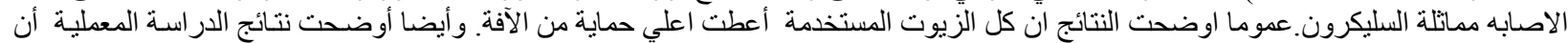

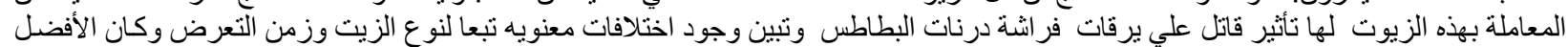

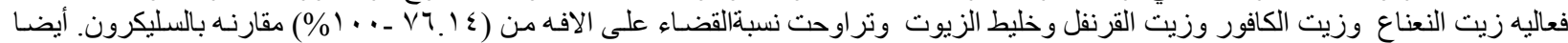

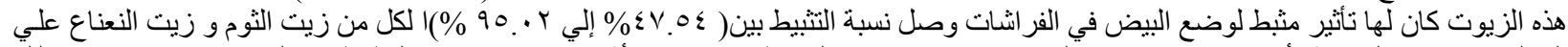

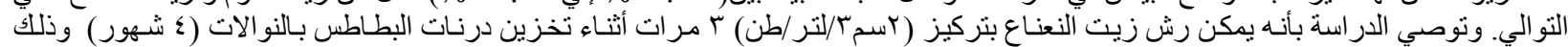

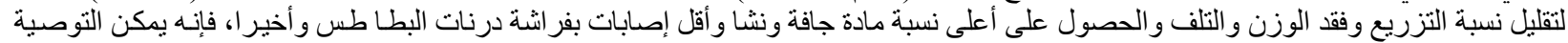

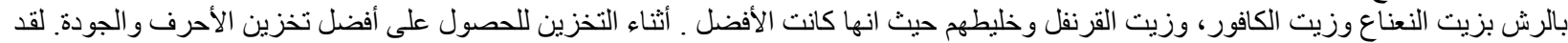

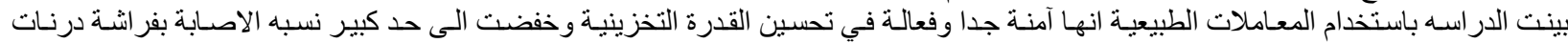

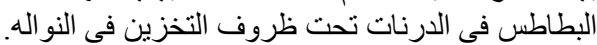

